\title{
Surface Roughness Evaluation in Milling of Strenx 1100 Steel under MQL Conditions
}

\author{
Mustafa Kuntoğlu ${ }^{1 *}$ \\ 1* Selcuk University, Faculty of Technology, Departmant of Mechcanical Engineering, Konya, Turkey, (ORCID: 0000-0002-7291-9468), mkuntoglu@ selcuk.edu.tr
}

(First received 22 April 2021 and in final form 5 July 2021)

(DOI: $10.31590 /$ ejosat.925667)

ATIF/REFERENCE: Kuntoğlu, M. (2021). Surface Roughness Evaluation in Milling of Strenx 1100 Steel under MQL Conditions. European Journal of Science and Technology, (25), 509-516.

\begin{abstract}
Strenx 1100 is one of the most important structural steel characterized by upmost mechanical properties, generally preferred for loadbearing applications at many engineering fields such as marine and crane. Minimum quantity lubrication (MQL) is a method that presents sustainable machining with applying pulverized oil into the cutting zone, proved it by obtaining better machinability characteristics compared to conventional approaches. Surface roughness is a response parameter reflects the quality of a machined part in a certain degree which should be produced as per the industrial requirements. This paper focuses on the surface roughness $(\mathrm{Ra})$ evaluation of Strenx 1100 steel during milling under MQL conditions. Taguchi design of experiments were utilized with combining three levels of cutting speed $\left(\mathrm{v}_{\mathrm{C}}\right)$, feed rate (f) and depth of cut $\left(\mathrm{a}_{\mathrm{P}}\right)$ in order to create $\mathrm{L}_{9}$ orthogonal array. The findings are discussed using analysis of variance (ANOVA), signal-to-noise ratio $(\mathrm{S} / \mathrm{N})$ based optimization and $3 \mathrm{~d}$ surface plots. According to the results, it is observed that the first level of cutting parameters namely $\mathrm{v}_{\mathrm{C}}=75 \mathrm{~m} / \mathrm{min}, \mathrm{f}=0.075 \mathrm{~mm} / \mathrm{rev}$ and $\mathrm{a}_{\mathrm{P}}=0.25 \mathrm{~mm}$ need to be selected for optimization of response parameter while feed rate has more influence $(66.9 \%)$ than depth of cut $(22.5 \%)$ and cutting speed $(0.4 \%)$ on surface roughness. Graphical representations exhibit the general trend of surface roughness which provides chance to selection of accurate cutting conditions for required response value.
\end{abstract}

Keywords: Strenx 1100 Steel, Surface Roughness, Milling, Minimum Quantity Lubrication.

\section{Strenx 1100 Çeliğinin MMY Şartları Altında Frezelenmesinde Yüzey Pürüzlülüğü Değerlendirmesi}

$\ddot{O} z$

Strenx 1100 üstün mekanik özellikler ile nitelendirilen, gemi ve vinç gibi birçok mühendislik alanında genellikle yük taşıma uygulamalarında tercih edilen en önemli yapı çeliklerinden bir tanesidir. Minimum Miktarda Yağlama (MMY) kesme bölgesine pulverize olmuş yağ uygulanması ile sürdürülebilir imalatı sağlayan, geleneksel yaklaşımlarla kıyaslandığında kendisini daha iyi işlenebilirlik karakteristikleri ile ispatlamış bir yöntemdir. Yüzey pürüzlülügü̈, endüstriyel ihtiyaçlara göre üretilmesi gereken, işlenen parçanın kalitesini belirli ölçüde yansıtan bir cevap parametresidir. Bu makale MMY şartları altında Strenx 1100 malzemenin frezelenmesi süresince yüzey pürüzlülüğünün değerlendirilmesi üzerine odaklanmıştır. Kesme hızı ( $\mathrm{v}_{\mathrm{C}}$ ), ilerleme (f) and talaş derinliğinin $\left(\mathrm{a}_{\mathrm{P}}\right)$ üç seviyesi birleştirilerek $\mathrm{L}_{9}$ ortogonal dizi oluşturulması için Taguchi deneysel tasarımından yararlanılmıştır. Bulgular, varyans analizi (ANOVA), sinyal-gürültü oranına $(\mathrm{S} / \mathrm{N})$ dayalı optimizasyon ve 3d yüzey grafikleri kullanılarak tartışllmıştır. Sonuçlara göre, ilerleme (66.9\%), yüzey pürüzlülüğü üzerinde talaş derinliği $(22.5 \%)$ ve kesme hızından $(0.4 \%)$ daha etkili olurken, kesme parametrelerinin birinci seviyesinin, $\mathrm{v}_{\mathrm{C}}=75 \mathrm{~m} / \mathrm{dak}$, $\mathrm{f}=0.075 \mathrm{~mm} / \mathrm{dev}$. ve $\mathrm{a}_{\mathrm{P}}=0.25 \mathrm{~mm}$, cevap parametresini optimize etmek için seçilmesi gerektiği görülmektedir. İstenen cevap değeri için doğru kesme koşullarının seçimini sağlayan grafiksel gösterimler yüzey pürüzlülüğünün genel eğilimlerini yansıtmaktadır.

Anahtar Kelimeler: Strenx 1100 Çeliği, Yüzey Pürüzlülüğü, Frezeleme, Minimum Miktarda Yağlama.

\footnotetext{
* Corresponding Author: mkuntoglu@ selcuk.edu.tr
} 


\section{Introduction}

Structural steels are the mostly preffered materials which requires lighter and stronger featured constructions. Typically, good weldability is needed for the joining of these cut-to-lenght materials in order to obtain huge components for the applications particularly in transportation. This class of steels need welding grooves which further necessitates machining operations during the production process of the mentioned large parts. Strenx 1100 is a special type of structural steels having important mechanical properties such as yield strength and tensile strength. The steel seems as appropriate for the load-bearing applications such as lifting crane sector, loaders, excavators, manufacturing of heavy vehicles and marine engineering (Kurc-Lisiecka, Piwnik, \& Lisiecki, 2017) (SSAB, 2021). Despite its prominent advantages in the usage area, the high strength originated from chemical composition make Strenx 1100 hard-to-cut material. Broadly, due to their sheet-shaped fabrication in industry, several operations can be performed on these materials by milling.

Today, wide range of hard materials need to be machined due to their high potential in industrial applications (Davim, 2011). Since their machining is difficult compared to conventional materials, many attempts have been made previously (Das, Pradhan, Patel, Das, \& Biswal, 2019; Kene \& Choudhury, 2019; Sun, Brandt, \& Dargusch, 2010). Typically, poor surface roughness and reduced tool life are characterized features of low machinability of hard metals. Mostly, high cutting forces and temperatures are accepted as the main reason of this result (Hosseini, Beno, Klement, Kaminski, \& Ryttberg, 2014). Recently, in order to improve machinability characteristics, cooling/lubrication systems have been integrated into machine tools (Boswell, Islam, Davies, Ginting, \& Ong, 2017) (Goindi \& Sarkar, 2017). Despite the investment cost in addition to consistent lubricant or gas consumption, their effect on the minimization of cutting temperatures and cutting forces make the cutting process much easier. On the other hand, cutting fluids have several negative effects on environment and human health (Ming et al., 2021). In this perspective, MQL technique has been applied from many researchers in order to reach sustainable manufacturing conditions in the last years. This method provide enhanced cutting operation with minimum ecological hazard (Shokoohi, Khosrojerdi, \& Shiadhi, 2015). Therefore, MQL assisted machining and especially milling of hard-to-cut materials became very popular. Basically, MQL provides sustainable machining as giving the pulverized oil to the cutting area instead of ejaculating as is in the flood cooling (Çetindağ, Çiçek, \& Uçak, 2020). Primary advantage in here is to supply pulverized oil sufficiently into the cutting zone with reducing coefficient of friction and cutting temperatures. Seemingly, they are much more effective than dry and flood cooling conditions for improved machinability.

In the past, a variety of papers have been published considering the valuable effects of pure-MQL or additive MQL methods in milling of hard materials. Among them, a handful of paper have been investigated the effect of MQL application on surface roughness. In a paper (Do \& Le, 2019), Taguchi design based MQL employment was tried for obtaining optimum cutting conditions in order to produce minimum surface roughness of AISI H13 steel. They analyzed and predicted the results and showed the applicability of MQL technique on hard milling. A study performed on the optimization of parameters for surface roughness in hard milling of AISI H13 steel under different MQL conditions with several ingredients (Hsu, 2016). On another work, Mihn et al. (Minh, The, \& Bao, 2017) measured the performance of nanofluid addition on surface roughness during hard milling of $60 \mathrm{Si}_{2} \mathrm{Mn}$ steel. According to the researchers (Jamil et al., 2021), MQL conditions produced better surface roughness compared to dry milling. In milling of AISI O2 using MQL system, borax and boric acid additives were used in order to improve machinability. Promising results were obtained by using different additives which presented also ecofriendly machining environment. A mathematical modeling approach was developed via response surface methodology and Taguchi method in end milling of AISI 4140 (Mia, 2018). This MQL assisted experimental work was analyzed statistically as well. Bashir et al. investigated surface milling of AISI 4140 steel under MQL conditions (Al Bashir, Mia, \& Dhar, 2018). Accordingly, better surface quality and machining characteristics were obtained by MQL utilization. Khaliq et al. studied about the surface quality of Ti-6Al-4V material comparing dry and MQL conditions which showed the superiority of MQL method at the end (Khaliq, Zhang, Jamil, \& Khan, 2020). MQL adapted milling was performed on another study (Iqbal, Ning, Khan, Liang, \& Dar, 2008) for modeling the effects of cutting parameters for hardened steels while considering tool life. Wang et al. evaluated the effect of MQL on milling of Inconel 182 material (Wang, Li, Chen, \& Liu, 2015). It seemed that MQL application had no significant impact on optimum parameters in order to obtain minimum surface roughness when compared with dry cutting. Hassanpour et al. researched surface roughness in hard milling of AISI 4340 steel for measuring the effects of basic cutting parameters (Hassanpour, Sadeghi, Rasti, \& Shajari, 2016). During milling of Hastelloy C276, nanofluid participation was experimented from authors (Günan, Kıvak, Yıldırım, \& Sarkaya, 2020) under MQL conditions. Optimum cutting parameters were found for minimum surface roughness in addition to tool wear mechanisms. In milling of Inconel 718, MQL was applied for surface roughness improvement in the perspective of sustainable machining (Anand \& Mathew, 2020). Gupta et al. focused on sustanability as well considering machinability of Inconel 800 in order to demonstrate the effect of cooling conditions (Gupta et al., 2018). As it can be seen, a number of paper have been published for performance improvement and increasing the machinability of hard steels via MQL system for many workpiece material.

Despite many works performed in the literature about hard machining and eco-friendly milling, none of them focused on the sustainable milling of Strenx 1100 structural steel. From this point of view, the presented paper investigates surface roughness of the Strenx 1100 steel during milling under MQL conditions. Taguchi based experimental design was adopted using 3 levels of cutting speed, feed rate and depth of cut. The obtained results were evaluated with statistical analysis and $3 \mathrm{~d}$ plot graphs in order to observe the effects of the cutting parameters. Also, optimizations of the parameters were carried out to obtain the best milling parameters.

\section{Material and Method}

\subsection{Cutting Tool and Workpiece Materials Specifications}

During the experiments, cutting tool inserts coded as APXT 1604 PDSR-MM TIN (Korloy) were utilized for milling. As per 
standardized experimentation, a separate cutting insert was used for each test. In addition, cutting tool holder coded 403 BT 40 ER32 x 70 (Mas) was selected.

In the experiments, quenched-tempered Strenx 1100 steel having $32 \mathrm{HRC}$ is used with the dimensions of $100 \times 100 \times 40$ $\mathrm{mm}$. The chemical composition (Table 1) and mechanical properties (Table 2) are given in the following Tables. In order to determine cutting conditions, recommendations of manufacturer were considered.

Table 1. Chemical composition of the material (SSAB, 2021)

\begin{tabular}{c|c|c|c|c|c|c|c|c|c|c}
\hline $\mathbf{F e}$ & $\mathbf{C}$ & $\mathbf{S i}$ & $\mathbf{M n}$ & $\mathbf{P}$ & $\mathbf{S}$ & $\mathbf{C r}$ & $\mathbf{C u}$ & $\mathbf{N i}$ & $\mathbf{M o}$ & $\mathbf{B}$ \\
\hline Bal. & 0.21 & 0.5 & 1.4 & 0.02 & 0.005 & 0.8 & 0.3 & 3 & 0.7 & 0.005 \\
\hline
\end{tabular}

Table 2. Mechnanical properties of the material (SSAB, 2021)

\begin{tabular}{c|c|c}
\hline $\begin{array}{c}\text { Yield Strenght } \\
(\mathbf{m i n} . \mathbf{M P a})\end{array}$ & $\begin{array}{c}\text { Tensile Strenght } \\
\text { (MPa) }\end{array}$ & $\begin{array}{c}\text { Elongation } \\
(\text { min. \%) }\end{array}$ \\
\hline 1100 & $1250-1550$ & 10 \\
\hline
\end{tabular}

\subsection{Machine Tool and Experiments}

Experiments were performed under MQL conditions applying three cutting speeds $(75-150-225 \mathrm{~m} / \mathrm{min})$, feed rates (0.075-0.15-0.225 $\mathrm{mm} / \mathrm{rev}$ and depth of cut values $(0.25-0.5-$ $0.75 \mathrm{~mm}$ ) respectively. Experimental tests were performed on rigid-structured $\mathrm{CNC}$ milling machine (DAHLIL). Before the experiments, comprehensive preliminary tests were carried out including wider range of cutting parameters. Then, considering the chips formation and chatter vibrations due to the highstrenght structure of Strenx 1100 some parameters were eliminated. Eventually nine experimental lines were composed according to design of experiments. All experiments were repeated three times in order to obtain guaranteed experimental results and check the validity.

MQL system has two different parts including nozzle and supply unit. The oil used is KT 2000 injected by lubrication system (Werte) having $24 \mathrm{~V}$ AC/DC working voltage, 4 bars operational pressure and $50 \mathrm{ml} / \mathrm{h}$ with the amount of lubrication in unit time. The nozzle was placed as close as possible to the cutting area for obtaining standart oili supply to the cutting zone and fixed to tool holder for simultaneous motion with machining system. Figure 1 shows the experimental setup in detail and separately the workpiece material, MQL unit, machine tool and schematical abstract of the paper.

\subsection{Taguchi Based Experimental Design}

Taguchi experimental design is a fully accepted method which further enables to perform analysis and optimization for minimum number of experiments (Debnath, Reddy, \& Yi, 2016). The importance of experimental design and optimization was approved from many authors in the past (Kuntoğlu \& Sağlam, 2019). Main contributions of the Taguchi method are minimum labor, costs and energy consumption to the experimental burden. Especially, Taguchi method provides robust and reliable design which further bring high quality and efficiency in terms of produced part and machining time (Kuntoğlu, Aslan, Sağlam, et al., 2020). Due to the high costs of the material used in this study, Strenx 1100, Taguchi method appealed in order to reach optimal solutions. Taguchi uses orthogonal arrays to reach minimum number of experiments. In Table 3, $\mathrm{L}_{9}$ orthogonal array based on Taguchi design is demonstrated. Accordingly, cutting parameters are matched with Taguchi design parameters.

Table 3. Taguchi based experimental design

\begin{tabular}{|c|c|c|}
\hline $\begin{array}{c}\mathrm{v}_{\mathrm{C}} \\
(\mathrm{m} / \mathrm{min}) \\
\mathrm{A}\end{array}$ & $\begin{array}{c}\mathbf{f} \\
(\mathrm{mm} / \mathrm{rev}) \\
\text { B }\end{array}$ & $\begin{array}{c}\mathrm{ap}_{\mathbf{P}} \\
(\mathrm{mm}) \\
\mathrm{C}\end{array}$ \\
\hline 1 & 1 & 1 \\
\hline 1 & 2 & 2 \\
\hline 1 & 3 & 3 \\
\hline 2 & 1 & 2 \\
\hline 2 & 2 & 3 \\
\hline 2 & 3 & 1 \\
\hline 3 & 1 & 3 \\
\hline 3 & 2 & 1 \\
\hline 3 & 3 & 2 \\
\hline
\end{tabular}

Taguchi refers to $\mathrm{S} / \mathrm{N}$ ratio and objective function in order to determine performance characteristics (Bensouilah et al., 2016). Therefore, deviation of these characteristics was calculated by objective functions. In addition, Taguchi uses orthogonal arrays for ensuring to use minimum number of experiments while reducing the noise factors at the same time (Akıncioğlu, Gökkaya, \& Uygur, 2016). There are three types of objective functions in the Taguchi design for determination of the desired approach for optimum value. Each approach set forth an equation according to the situation of the response parameter and requirements, namely, maximization, minimization and normalization. In this work, owing to the surface roughness is desired as small as possible, objective function is selected as smaller is better, as shown in the following:

$$
\mathrm{S} / \mathrm{N} \text { smaller is the better }=-10 \log \left[\frac{1}{n} \sum_{i=1}^{n} y_{i}^{2}\right]
$$

\subsection{Surface Roughness Measurement}

Surface roughness was measured by roughness tester device (Insize ISR C100) after the milling experiments. After each test, measurements were taken from the machined surface for five times. Then, the lowest and the highest values were eliminated to avoid high deviations, the mean of the three values were calculated. Also, the calibration of the device was performed in order to prevent deviations.

For the evaluation of surface roughness, mostly used roughness parameter, arithmetical average value, Ra was selected. Ra uses long sampling rate which provides insensitivity to instant changes occur during machining. The parameter was preferred from many authors at the past (Kuntoğlu, Aslan, Sağlam, et al., 2020; Şap, Usca, Gupta, \& Kuntoğlu, 2021; Şap, Usca, Gupta, Kuntoğlu, et al., 2021). The calculation of the surface roughness is represented in Equation 2. Here, Lm is the distance measured, and $\mathrm{y}$ is the deviation from the nominal surface.

$$
\mathrm{Ra}=\int_{0}^{L m} \frac{|y|}{L m} \quad \mathrm{dx}
$$



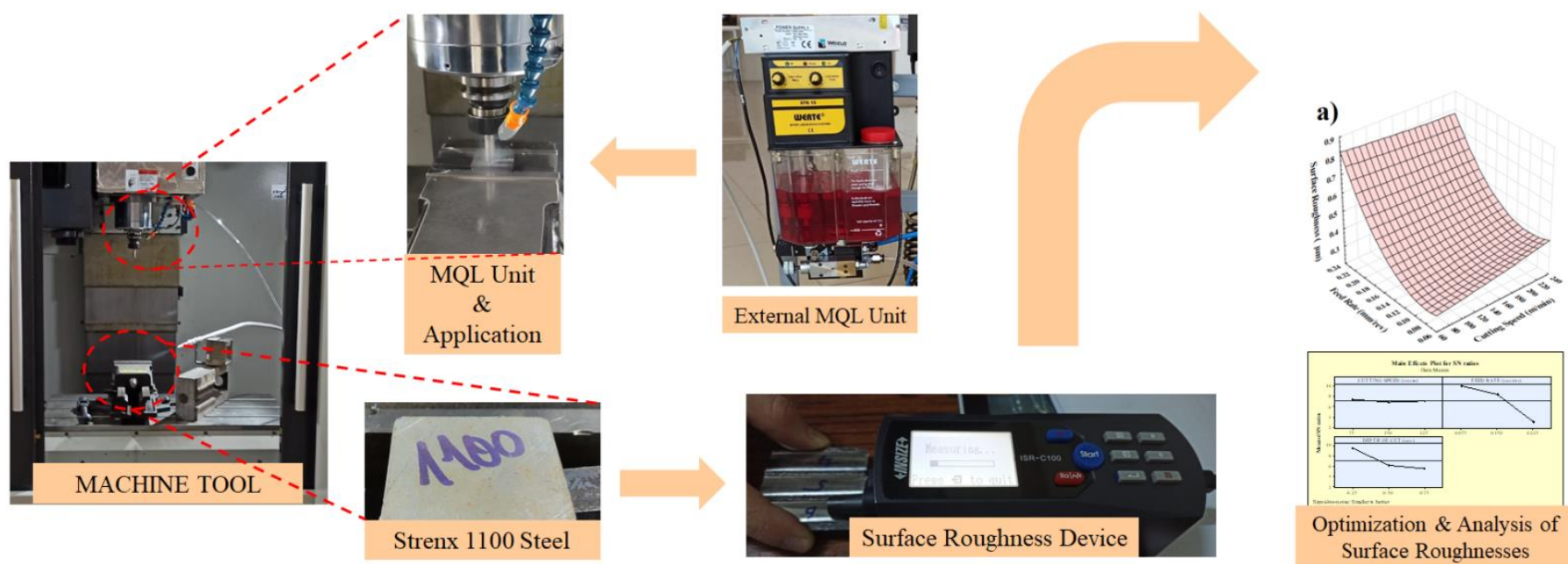

Figure 1. Experimental setup, measurement and graphical abstract

\section{Results and Discussion}

Surface roughness stands one of the important surface characteristics of a component produced (Şahinoğullari \& Luş, 2021). Surface roughness has also practical significance with its potential to decrease down or increase up to a certain value by applying additional procedures. Therefore, it's crucial to monitor and measure the surface roughness parameters in a number of engineering fields. As mentioned before, L9_orthogonal array design was adopted to the experimental work with using cutting speed, feed rate and depth of cut parameters. Experimental scheme and obtained surface roughness values are listed in Table 4.

Table 4. Cutting parameters used in the experiments and obtained surface roughness values

\begin{tabular}{c|c|c|c}
\hline $\begin{array}{c}\text { CUTTING SPEED } \\
(\mathbf{m} / \mathbf{m i n})\end{array}$ & $\begin{array}{c}\text { FEED RATE } \\
(\mathbf{m m} / \mathbf{r e v})\end{array}$ & $\begin{array}{c}\text { DEPTH OF CUT } \\
(\mathbf{m m})\end{array}$ & $\begin{array}{c}\text { SURFACE ROUGHNESS } \\
(\boldsymbol{\mu \mathbf { m }})\end{array}$ \\
\hline 75 & 0.075 & 0.25 & 0.234 \\
\hline 75 & 0.15 & 0.5 & 0.482 \\
\hline 75 & 0.225 & 0.75 & 0.686 \\
\hline 150 & 0.075 & 0.5 & 0.305 \\
\hline 150 & 0.15 & 0.75 & 0.478 \\
\hline 150 & 0.225 & 0.25 & 0.646 \\
\hline 225 & 0.075 & 0.75 & 0.442 \\
\hline 225 & 0.15 & 0.25 & 0.247 \\
\hline 225 & 0.225 & 0.5 & 0.79
\end{tabular}

\subsection{Graphical Analysis}

As being a functional parameter of the manufactured component, surface roughness is a representative for understanding the machining quality. The main reason for the selection of surface roughness as machinability criteria in the past is being a prerequisite from receivers in the market. Basically, for the determination of component life and operational performance, surface roughness can be accepted as a good indicator (Mia \& Dhar, 2018). Among all machining parameters, surface roughness exists one of the significant evaluation factors for workpiece as reflecting the surface morphology.

Surface roughness is affected from many factors during milling such as tool wear, disrupted tool geometry, chatter vibrations, high cutting forces etc. Besides, correct selections of cutting parameters and machine tool structure have great importance especially for precision engineering (Wojciechowski,
Maruda, Krolczyk, \& Niesłony, 2018). Additionally, workpiece and cutting tool hardness and mechanical properties contributes to the production process. Theoretically, optimal parameters need to be found for the best surface roughness however, there are some allowances for this aim such as high cutting speed and low feed rate etc. From this point of view, the handled material is evaluated from the accumulated knowledge with $3 \mathrm{~d}$ surface plots.

Discussion is performed on the arithmetical average value, $\mathrm{Ra}$ and demonstrated in Figure 2 according to combined effects of cutting speed, feed rate and depth of cut. When Figure $2 \mathrm{a}$ is considered, dominance of feed rate can be seen compared to cutting speed. Due to the feed rate is a function of surface roughness, it is expected that increasing feed rate increases surface roughness (Koklu \& Çoban, 2020). Accordingly, with lower values of feed rate, roughness traces became more clear and that situation produce rough surface (Wu et al., 2018). The 
effect of cutting speed can be avoided according to the Figure $2 \mathrm{a}$.

In Figure $2 b$, it can be observed that increasing depth of cut increases surface roughness. Same situation was observed from authors (Hassanpour et al., 2016) in hard milling under MQL conditions. Cutting speed has fluctuating effect on surface roughness according to changing depth of cut values. As expected, increasing cutting speed softens the workpiece material and makes easier cutting process. This reduces cutting temperatures and tool wear progression and indirectly improves surface roughness (Hassanpour et al., 2016). This influnce slightly reduces at higher depth of cut values. This can be attributed to the better contact conditions between cutting tool and workpiece which develops the cutting ability of tool.

Figure 2c demonstrates the improvement effect of the combination of feed rate and depth of cut. This is due to the reduced plowing effect which can be eliminated at low depth of cut and high feed rate values owing to reduced uncut chip thickness (Cui, Zhao, Jia, \& Zhou, 2012). As feed rate increases, the slope of the suface roughness curve increases as well. This situation comes from the equation defines the relationship between the square of feed rate and surface roughness (Kuntoğlu, Aslan, Pimenov, et al., 2020). The effect of depth of cut seems ignorable after a certain value of feed rate.
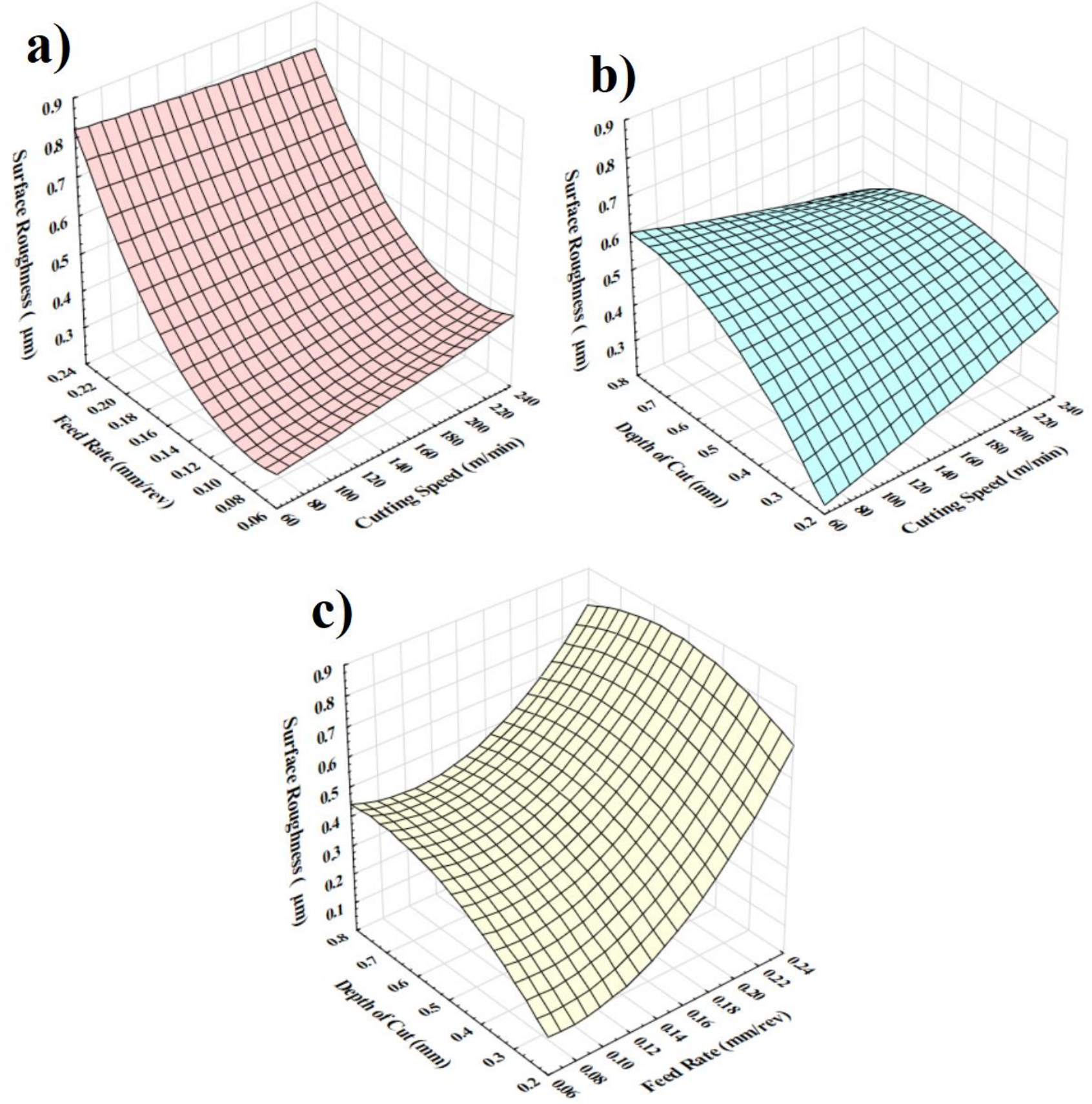

Figure 2. 3d plots for the combined effect of cutting parameters on surface roughness

\subsection{Optimization of Parameters for Surface Roughness}

Optimization aims to find the best conditions in an engineering problem substantially. In the machining perpective, any input namely cutting parameters, tool geometry components, lubrication conditions, material specifications can be optimized 
for all response parameters such as tool wear, cutting forces, surface roughness etc. In this context, Taguchi based $\mathrm{S} / \mathrm{N}$ ratios were used in order to minimize surface roughness with optimizing cutting speed, feed rate and depth of cut values as represented in Figure 3. In the graphs, three levels of cutting parameters are ordered with calculating the $\mathrm{S} / \mathrm{N}$ ratios. Accordingly, first levels of all parameters should be selected in order to obtain minimum surface roughness. When looking to the experimental results in Table 4, Taguchi findings can be validated. Also, in Figure 2, lowest surface roughness values are observed at these cutting conditions as well. The harmony between graphs and optimum results shows the robustness of Taguchi design and applicability of this method in milling of Strenx 1100 steel under MQL conditions with high reliability.

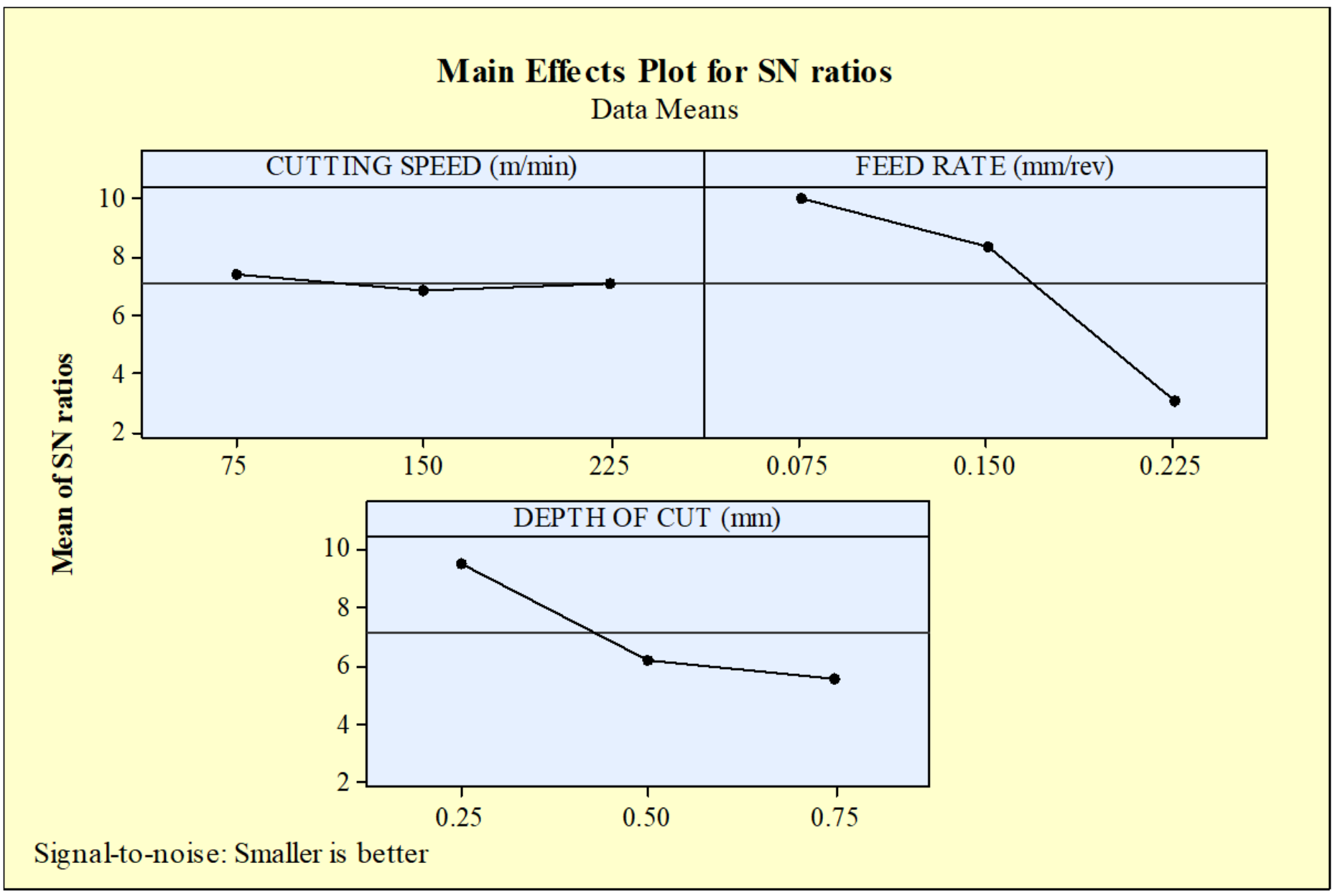

Figure 3. Optimum cutting parameters for minimum surface roughness

\subsection{Analysis of Variance Results}

Anova provides the amount of effectiveness of each parameter on the response parameter. This analysis presents statistical approach essentially using several calculation methods. Anova is utilized in wide range applications in engineering field. From the point of view of machining operations, the changes at cutting parameters may have outstanding influence on variables due to the complex structure of machining and interrelated interactions between parameters. The knowledge about parameter effects help researchers and manufacturers to understand the underlying mechanism of any metal cutting operation. This further brings to tune the input parameters and pave the way for optimization.
Table 5 demonstrates Anova results for surface roughness for each source and their statistical importance in terms of three criteria. According to this analysis, feed rate seems as the dominant parameter $(66.9 \%)$ on surface roughness, followed by depth of cut $(22.5 \%)$ for the evaluation with percent contribution (PC). Seemingly, cutting speed $(0.4 \%)$ has no important influence on surface roughness. On the other hand, $F$ value and $P$ value show the same results about the parameter effect. In a nutshell, graphical representation, optimization and statistical analysis results support each other which show the consistency of the applied methods. 
Table 5. Analysis of variance results for surface roughness

\begin{tabular}{c|c|c|c|c|c|c}
\hline Source & DF & Seq. SS & Adj. MS & F-value & P-value & PC (\%) \\
\hline Cutting Speed & 2 & 0.488 & 0.2438 & 0.04 & 0.961 & 0.4 \\
\hline Feed Rate & 2 & 79.144 & 39.5719 & 6.54 & 0.133 & 66.9 \\
\hline Depth of Cut & 2 & 26.626 & 13.3131 & 2.20 & 0.312 & 22.5 \\
\hline Residual Error & 2 & 12.1 & 6.0499 & - & - & 10.2 \\
\hline Total & 8 & 118.357 & - & - & - & 100 \\
\hline
\end{tabular}

\section{Conclusions and Recommendations}

Its very crucial in today's rivalry manufacturing world to reach the best machining conditions for high quality components. Besides, developing environmentally friendly machining conditions is an inevitable requirement for the purpose of green manufacturing. This study focuses on the surface roughness assessment during milling of Strenx 1100 steel for the first time in literature. Considering sustainable machining by using MQL, cutting speed, feed rate and depth of cut values are utilized to create experimental plan. The experimental results are evaluated using $3 \mathrm{~d}$ surface plots, $\mathrm{S} / \mathrm{N}$ ratio of Taguchi and Anova methods. From the obtained results, following deductions can be performed:

1. According to the graphical analysis, feed rate showed peculiar influence on surface roughness irrespective of depth of cut or cutting speed values. A direct proportion can be observed with feed rate and surface roughness which is attributed to the situation that the feed rate is function of surface roughness. Increasing depth of cut increases surface roughness especially for the lower feed rate and cutting speed values. Reduced cutting ability of cutting tool due to the lower speeds produces rough surface.

2. Taguchi's $\mathrm{S} / \mathrm{N}$ ratios demonstrated that first level of cutting speed, feed rate and depth of cut should be selected for the best surface roughness value.

3. When compared with the experimental results and graphical representations, Taguchi provided compatible suggestions which demonstrates the reliability of the method used.

4. First level of cutting parameters such as $\mathrm{v}_{C}=75 \mathrm{~m} / \mathrm{min}$, $\mathrm{f}=0.075 \mathrm{~mm} / \mathrm{rev}$ and $\mathrm{a}_{\mathrm{P}}=0.25 \mathrm{~mm}$ need to be chosen for minimization of surface roughness.

5. Lastly, Anova results indicated that feed rate is the dominant factor on surface roughness (66.9\%) and followed by depth of cut $(22.5 \%)$ and cutting speed $(0.4 \%)$ respectively.

6. And according to the F-values, feed rate is the most effective parameter (6.54) on surface roughness. Then depth of cut (2.20) and cutting speed (0.04) follow it.

7. In a word, evaluation methods for surface roughness of Strenx 1100 steel in MQL assisted milling provide reliable solutions for the best machining conditions. This shows that general approach presented in this work can be applicable in industrial applications. And finally, this can be an efficient way for the sustainable milling of hard materials in the future.

\section{References}

Akıncıoğlu, S., Gökkaya, H., \& Uygur, İ. (2016). The effects of cryogenic-treated carbide tools on tool wear and surface roughness of turning of Hastelloy $\mathrm{C} 22$ based on Taguchi method. The International Journal of Advanced Manufacturing Technology, 82(1-4), 303-314.

Al Bashir, M., Mia, M., \& Dhar, N. R. (2018). Investigations on surface milling of hardened AISI 4140 steel with pulse jet MQL applicator. Journal of the Institution of Engineers (India): Series C, 99(3), 301-314.

Anand, K., \& Mathew, J. (2020). Evaluation of size effect and improvement in surface characteristics using sunflower oilbased MQL for sustainable micro-endmilling of Inconel 718. Journal of the Brazilian Society of Mechanical Sciences and Engineering, 42(4), 1-13.

Bensouilah, H., Aouici, H., Meddour, I., Yallese, M. A., Mabrouki, T., \& Girardin, F. (2016). Performance of coated and uncoated mixed ceramic tools in hard turning process. Measurement, 82, 1-18.

Boswell, B., Islam, M. N., Davies, I. J., Ginting, Y., \& Ong, A. K. (2017). A review identifying the effectiveness of minimum quantity lubrication (MQL) during conventional machining. The International Journal of Advanced Manufacturing Technology, 92(1), 321-340.

Cui, X., Zhao, J., Jia, C., \& Zhou, Y. (2012). Surface roughness and chip formation in high-speed face milling AISI H13 steel. The International Journal of Advanced Manufacturing Technology, 61(1), 1-13.

Çetindağ, H. A., Çiçek, A., \& Uçak, N. (2020). The effects of CryoMQL conditions on tool wear and surface integrity in hard turning of AISI 52100 bearing steel. Journal of Manufacturing Processes, 56, 463-473.

Das, A., Pradhan, O., Patel, S. K., Das, S. R., \& Biswal, B. B. (2019). Performance appraisal of various nanofluids during hard machining of AISI 4340 steel. Journal of Manufacturing Processes, 46, 248-270.

Davim, J. P. (2011). Machining of hard materials: Springer Science \& Business Media.

Debnath, S., Reddy, M. M., \& Yi, Q. S. (2016). Influence of cutting fluid conditions and cutting parameters on surface roughness and tool wear in turning process using Taguchi method. Measurement, 78, 111-119.

Do, T.-V., \& Le, N.-A.-V. (2019). Optimization of surface roughness and cutting force in MQL hard-milling of AISI H13 steel. Paper presented at the Advances in Engineering Research and Application: Proceedings of the International Conference, ICERA 2018.

Goindi, G. S., \& Sarkar, P. (2017). Dry machining: a step towards sustainable machining-challenges and future directions. Journal of cleaner production, 165, 1557-1571. 
Gupta, M. K., Pruncu, C. I., Mia, M., Singh, G., Singh, S., Prakash, C., . . . Gill, H. S. (2018). Machinability investigations of Inconel-800 super alloy under sustainable cooling conditions. Materials, 11(11), 2088.

Günan, F., Kıvak, T., Yıldırım, Ç. V., \& Sarıkaya, M. (2020). Performance evaluation of MQL with AL2O3 mixed nanofluids prepared at different concentrations in milling of Hastelloy C276 alloy. Journal of Materials Research and Technology, 9(5), 10386-10400.

Hassanpour, H., Sadeghi, M. H., Rasti, A., \& Shajari, S. (2016). Investigation of surface roughness, microhardness and white layer thickness in hard milling of AISI 4340 using minimum quantity lubrication. Journal of cleaner production, 120, 124-134.

Hosseini, S., Beno, T., Klement, U., Kaminski, J., \& Ryttberg, K. (2014). Cutting temperatures during hard turningMeasurements and effects on white layer formation in AISI 52100. Journal of materials processing technology, 214(6), 1293-1300.

Hsu, Q.-C. (2016). Optimization of minimum quantity lubricant conditions and cutting parameters in hard milling of AISI H13 steel. Applied Sciences, 6(3), 83.

Iqbal, A., Ning, H., Khan, I., Liang, L., \& Dar, N. U. (2008). Modeling the effects of cutting parameters in MQLemployed finish hard-milling process using D-optimal method. Journal of Materials Processing Technology, 199(13), 379-390.

Jamil, M., Zhao, W., He, N., Gupta, M. K., Sarikaya, M., Khan, A. M., .. . Pimenov, D. Y. (2021). Sustainable milling of Ti6Al-4V: A trade-off between energy efficiency, carbon emissions and machining characteristics under MQL and cryogenic environment. Journal of cleaner production, 281, 125374.

Kene, A. P., \& Choudhury, S. K. (2019). Analytical modeling of tool health monitoring system using multiple sensor data fusion approach in hard machining. Measurement, 145, 118129.

Khaliq, W., Zhang, C., Jamil, M., \& Khan, A. M. (2020). Tool wear, surface quality, and residual stresses analysis of micro-machined additive manufactured $\mathrm{Ti}-6 \mathrm{Al}-4 \mathrm{~V}$ under dry and MQL conditions. Tribology International, 151, 106408.

Koklu, U., \& Çoban, H. (2020). Effect of dipped cryogenic approach on thrust force, temperature, tool wear and chip formation in drilling of AZ31 magnesium alloy. Journal of Materials Research and Technology, 9(3), 2870-2880.

Kuntoğlu, M., Aslan, A., Pimenov, D. Y., Giasin, K., Mikolajczyk, T., \& Sharma, S. (2020). Modeling of cutting parameters and tool geometry for multi-criteria optimization of surface roughness and vibration via response surface methodology in turning of AISI 5140 steel. Materials, 13(19), 4242.

Kuntoğlu, M., Aslan, A., Sağlam, H., Pimenov, D. Y., Giasin, K., \& Mikolajczyk, T. (2020). Optimization and analysis of surface roughness, flank wear and 5 different sensorial data via tool condition monitoring system in turning of aisi 5140. Sensors, 20(16), 4377.

Kuntoğlu, M., \& Sağlam, H. (2019). Investigation of progressive tool wear for determining of optimized machining parameters in turning. Measurement, 140, 427-436.

Kurc-Lisiecka, A., Piwnik, J., \& Lisiecki, A. (2017). Laser welding of new grade of advanced high strength steel
STRENX 1100 MC. Archives of Metallurgy and Materials, 62.

Mia, M. (2018). Mathematical modeling and optimization of MQL assisted end milling characteristics based on RSM and Taguchi method. Measurement, 121, 249-260.

Mia, M., \& Dhar, N. R. (2018). Modeling of surface roughness using RSM, FL and SA in dry hard turning. Arabian Journal for Science and Engineering, 43(3), 1125-1136.

Ming, W., Shen, F., Zhang, G., Liu, G., Du, J., \& Chen, Z. (2021). Green machining: A framework for optimization of cutting parameters to minimize energy consumption and exhaust emissions during electrical discharge machining of Al 6061 and SKD 11. Journal of cleaner production, 285, 124889.

Minh, D. T., The, L. T., \& Bao, N. T. (2017). Performance of $\mathrm{A} 12 \mathrm{O} 3$ nanofluids in minimum quantity lubrication in hard milling of $60 \mathrm{Si} 2 \mathrm{Mn}$ steel using cemented carbide tools. Advances in Mechanical Engineering, 9(7), 1687814017710618.

Shokoohi, Y., Khosrojerdi, E., \& Shiadhi, B. R. (2015). Machining and ecological effects of a new developed cutting fluid in combination with different cooling techniques on turning operation. Journal of cleaner production, 94, 330339.

SSAB.

(2021)

https://www.ssab.com.tr/api/sitecore/Datasheet/GetDocume nt?productId=6A0A9E9AF58C4AA2A29FC15CA0CE2590 \&language $=$ en

Sun, S., Brandt, M., \& Dargusch, M. (2010). Thermally enhanced machining of hard-to-machine materials-a review. International Journal of Machine Tools and Manufacture, 50(8), 663-680.

Şahinoğullari, E., \& Luş, H. M. (2021). Effect of Machining on the Surface Roughness of 31CrMoV9 and 34CrAIMo5 Steels After Nitriding. Avrupa Bilim ve Teknoloji Dergisi(21), 410-415.

Şap, E., Usca, U. A., Gupta, M. K., \& Kuntoğlu, M. (2021). Tool wear and machinability investigations in dry turning of $\mathrm{Cu} / \mathrm{Mo}-\mathrm{SiC} \mathrm{p}$ hybrid composites. The International Journal of Advanced Manufacturing Technology, 1-18.

Şap, E., Usca, Ü. A., Gupta, M. K., Kuntoğlu, M., Sarıkaya, M., Pimenov, D. Y., \& Mia, M. (2021). Parametric Optimization for Improving the Machining Process of $\mathrm{Cu} / \mathrm{Mo}-\mathrm{SiCP}$ Composites Produced by Powder Metallurgy. Materials, 14(8), 1921.

Wang, C., Li, K., Chen, M., \& Liu, Z. (2015). Evaluation of minimum quantity lubrication effects by cutting force signals in face milling of Inconel 182 overlays. Journal of cleaner production, 108, 145-157.

Wojciechowski, S., Maruda, R. W., Krolczyk, G. M., \& Niesłony, P. (2018). Application of signal to noise ratio and grey relational analysis to minimize forces and vibrations during precise ball end milling. Precision Engineering, 51, 582-596.

Wu, Q., Xie, D.-J., Si, Y., Zhang, Y.-D., Li, L., \& Zhao, Y.-X. (2018). Simulation analysis and experimental study of milling surface residual stress of Ti-10V-2Fe-3Al. Journal of Manufacturing Processes, 32, 530-537. 